\title{
Cold-formed steel sections with web openings subjected to web crippling under two-flange loading conditions-part I: Tests and finite element analysis
}

\author{
Asraf Uzzaman ${ }^{\text {a,* }}$, James B.P Lim ${ }^{\mathrm{b}}$, David Nash ${ }^{\mathrm{a}}$, Jim Rhodes $^{\mathrm{a}}$, Ben Young ${ }^{\mathrm{c}}$ \\ a Department of Mechanical and Aerospace Engineering, The University of Strathclyde, 75 Montrose Street, Glasgow G1 1XJ, United Kingdom \\ b SPACE, David Keir Building, Queen's University Belfast, Belfast, BT9 5AG, UK \\ ${ }^{\mathrm{c}}$ Department of Civil Engineering, The University of Hong Kong, Pokfulam Road, Hong Kong
}

\section{A R T I C L E I N F O}

\section{Article history:}

Received 12 February 2012

Accepted 12 March 2012

Available online 12 April 2012

Keywords:

Cold-formed steel

Web crippling

Finite element analysis

Web hole

Channel section

\begin{abstract}
A B S T R A C T
The results of 82 web crippling tests are presented, with 20 tests conducted on channel sections without web openings and 62 tests conducted on channel sections with web openings. The tests consider both end-two-flange and interior-two-flange loading conditions. In the case of the tests with web openings, the hole was located directly under the concentrated load. The concentrated load was applied through bearing plates; the effect of different bearing lengths is investigated. In addition, the cases of both flanges fastened and unfastened to the support is considered. A non-linear elasto-plastic finite element model is described, and the results compared against the laboratory test results; a good agreement was obtained in terms of both strength and failure modes.
\end{abstract}

(c) 2012 Elsevier Ltd. All rights reserved.

\section{Introduction}

Cold-formed steel sections are increasingly used in residential and commercial construction as both primary and secondary framing members. Web crippling at points of concentrated load or reaction is well known to be a significant problem, particularly in thin-walled beams [1]. To improve the buildability of buildings composed of cold-formed steel channel-sections, openings in the web are often required, for ease of installation of electrical or plumbing services.

The authors have previously described a combination of experimental tests and numerical analyses on cold-formed steel sections with circular web openings under the interior-two-flange (ITF) loading condition (Uzzaman et al. [2]). In the study described, the web holes were located at the mid-depth of the section with a horizontal clear distance of the web holes to the near edge of the bearing plate (Fig. 1). This paper considers the strength of cold-formed steel channel sections under interiortwo-flange and end-two-flange loading conditions, in which the web holes are located at the mid-depth of the webs and centred beneath the bearing plates (Figs. 2 and 3). The results are compared against tests that are also conducted on channel sections without holes. The cases of both flanges fastened and unfastened to the support are considered.

Yu and Davis [3], Sivakumaran and Zielonka [4], LaBoube et al. [5] and Chung [6] have conducted research on the effect of web

\footnotetext{
* Corresponding author. Tel.: +44 787768785 .

E-mail address: asraf.uzzaman@strath.ac.uk (A. Uzzaman).
}

openings on the web crippling strength of cold-formed steel channel sections. These studies have all focussed on the interior-one-flange (IOF) web crippling loading condition. More recently, Zhou and Young [7] have conducted research on aluminium alloy square hollow sections with circular holes located and centred beneath the bearing plates under interior-two-flange (ITF) and end-two-flange (ETF) loading conditions.

In buildings, web openings can either be centred beneath the load or reactions, or located with an offset distance to the bearing plate. Furthermore, the flanges can be either fastened or unfastened to the support. In the literature on web crippling with web openings, no research has been conducted on cold-formed steel sections under either ITF or ETF loading conditions, where the opening is located beneath the bearing plates.

A non-linear elasto-plastic finite element model was developed for cold-formed steel sections with web holes subjected to web crippling. The finite element program ANSYS [8] was adopted. Contact between the bearing plates and the specimen were modelled. The results are compared against the laboratory test results; a good agreement was obtained in terms of both strength and failure modes.

\section{Experiment investigation}

\subsection{Test specimens}

A test programme was conducted on lipped channel sections, as shown in Fig. 4, with circular web holes subjected to web 


\begin{tabular}{|c|c|c|c|}
\hline \multicolumn{2}{|c|}{ Nomenclature } & $N$ & Length of the bearing plate; \\
\hline$A$ & Web holes ratio; & & pling load per web; \\
\hline$b_{f}$ & Overall flange width of section; & $P_{\mathrm{FEA}}$ & Web crippling strength per web predicted from finite \\
\hline$b_{l}$ & Overall lip width of section; & & element (FEA); \\
\hline $\mathrm{COV}$ & Coefficient of variation; & $R$ & Reduction factor; \\
\hline FEA & Finite element analysis; & $t$ & Thickness of section; \\
\hline$f_{y}$ & Material yield strength; & $\varepsilon_{f}$ & Elongation (tensile strain) at fracture; \\
\hline$h$ & Depth of the flat portion of web; & $\sigma_{0.2}$ & Static $0.2 \%$ proof stress; and \\
\hline$L$ & Length of the specimen; & $\sigma_{u}$ & Static ultimate tensile strength. \\
\hline
\end{tabular}

crippling. The size of the web holes was varied in order to investigate the effect of the web holes on the web crippling strength. The circular holes with nominal diameters $(a)$ ranging from 40 to $240 \mathrm{~mm}$ were considered in the experimental investigation. The ratio of the diameter of the holes to the depth of the flat portion of the webs $(a / h)$ were $0.2,0.4,0.6$ and 0.8 . All the test

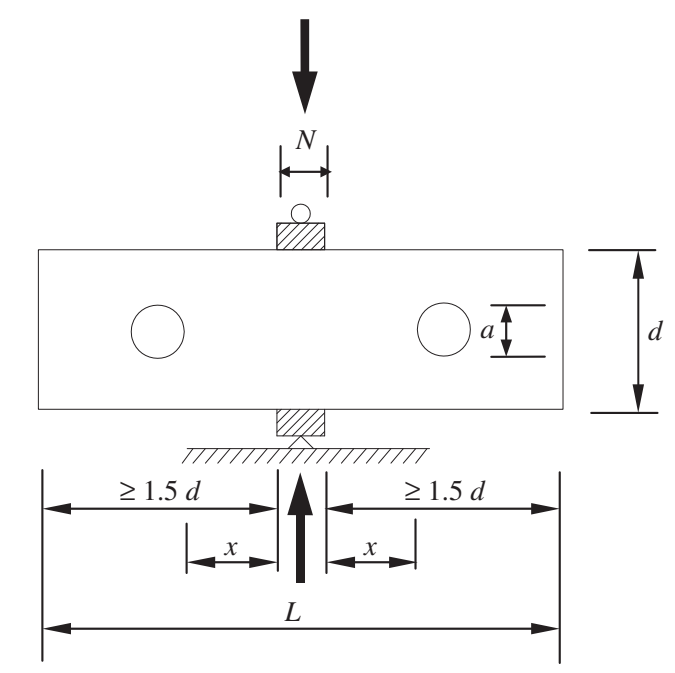

Fig. 1. ITF loading condition with offset web holes studied by Uzzaman et al. [2]. specimens were fabricated with web holes located at the middepth of the webs and centred beneath the bearing plates.

Channel sections without holes were also tested. The test specimens comprised five different section sizes, having nominal thicknesses ranging from 1.3 to $2.0 \mathrm{~mm}$; the nominal depth of the webs and the flange widths ranged from 142 to $302 \mathrm{~mm}$. The measured web slenderness $(h / t)$ values of the channel sections ranged from 116 to 176 . The specimen lengths $(L)$ were determined according to the NAS Specification [9]. Generally, the distance from the edge of the bearing plate to the end of the

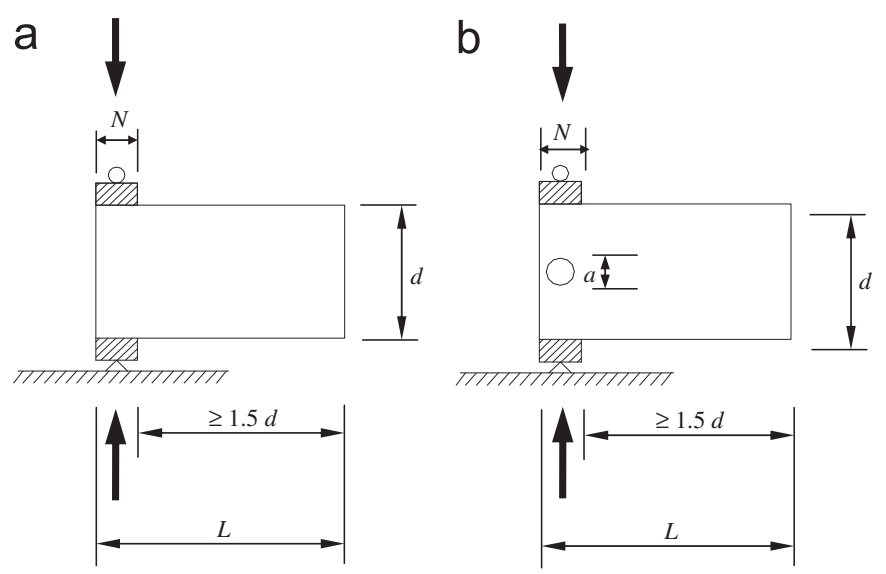

Fig. 3. ETF loading condition: (a) Without hole and (b) With hole. a

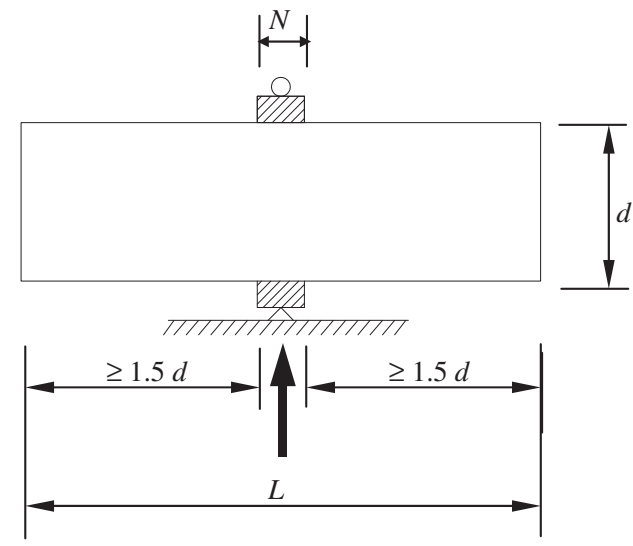

b
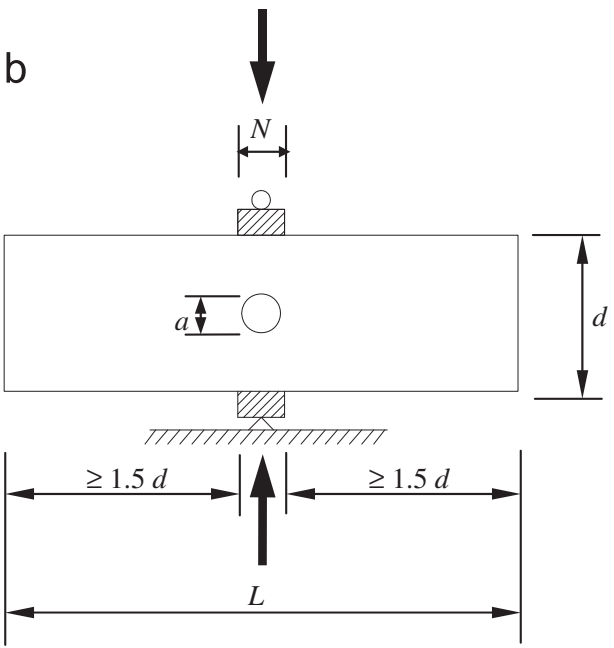

Fig. 2. ITF loading condition: (a) Without hole and (b) With hole. 
member was set to be 1.5 times the overall depth of the web $(d)$ rather than 1.5 times the depth of the flat portion of the web $(h)$, the latter being the minimum specified in the specifications. Tables 1-4 show the measured test specimen dimensions for the flange unfastened and fastened conditions, respectively, using the nomenclature defined in Figs. 2-4 for the ITF and ETF loading conditions. The bearing plates were fabricated using high strength steel having a thickness of $25 \mathrm{~mm}$. Three different lengths of bearing plates $(N)$ were used, namely, 90,120 and $150 \mathrm{~mm}$.

\subsection{Specimens labelling}

In Tables 1-4, the specimens were labelled such that the loading condition, the nominal dimension of the specimen and the length of the bearing as well as the ratio of the diameter of the holes to the depth of the flat portion of the webs $(a / h)$ could be identified from the label. For example, the labels "202 × $65 \times 13$-t1.4N120MA0FR"

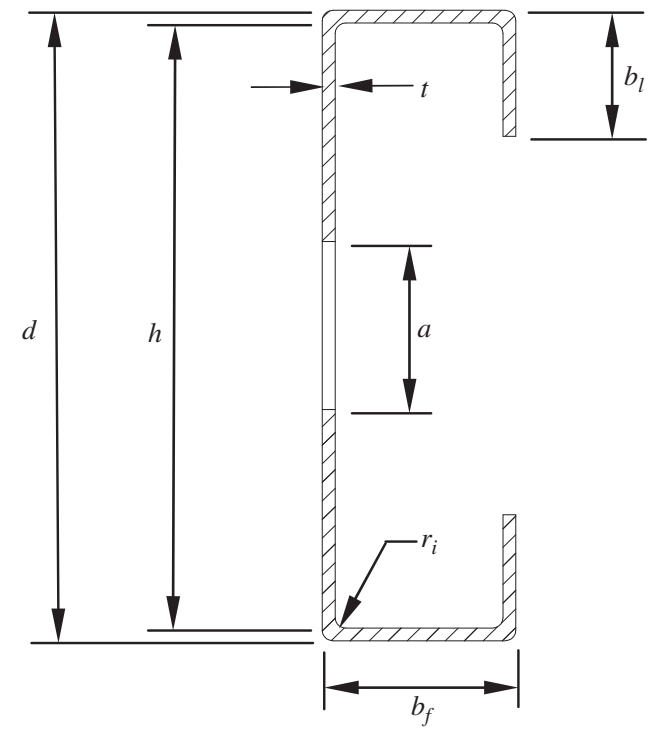

Fig. 4. Definition of symbols. and "202 $\times 65 \times 13-t 1.4$ N120MAOFX define the following specimens:

- The following symbols are the nominal dimensions $\left(d \times b_{f} \times b_{l^{-}}\right.$ t1.4) of the specimens in millimetres. $(202 \times 65 \times 13-\mathrm{t} 1.4$ means $d=202 \mathrm{~mm} ; b_{f}=65 \mathrm{~mm} ; b_{l}=13 \mathrm{~mm}$ and $t=1.4 \mathrm{~mm}$ )

- The notation "N120" indicates the length of bearing in millimetres i.e., $120 \mathrm{~mm}$.

- The last notations "MA0.2", "M'A0.4", "MA0.6" and "MA0.8" stand for the ratios of the diameter of the holes to the depth of the flat portion of the webs. Ratio of a/h were $0.2,0.4,0.6$ and 0.8. (A0.2 means $a / h=0.2$; A0.8 means $a / h=0: 8$ ).

- Twenty tests were conducted on the channel section specimens without web holes that are denoted by "MA0". FR means flanges unfastened to the support and FX means flanges fastened to the support.

\subsection{Material properties}

Tensile coupon tests were carried out to determine the material properties of the channel specimens. The tensile coupons were taken from the centre of the web plate in the longitudinal direction of the untested specimens. The tensile coupons were prepared and tested according to the British Standard for Testing and Materials [10] for the tensile testing of metals using $12.5 \mathrm{~mm}$ wide coupons of a gauge length $50 \mathrm{~mm}$. The coupons were tested in an MTS displacement controlled testing machine using friction grips. Two strain gauges and a calibrated extensometer of $50 \mathrm{~mm}$ gauge length were used to measure the longitudinal strain. The material properties obtained from the tensile coupon tests are summarised in Table 5, which includes the measured static $0.2 \%$ proof stress $\left(\sigma_{0.2}\right)$, the static tensile strength $\left(\sigma_{u}\right)$ and the elongation after fracture $\left(\varepsilon_{f}\right)$ based on a gauge length of $50 \mathrm{~mm}$.

\subsection{Test rig and procedure}

The specimens were tested under the interior-two-flange (ITF) and end-two-flange (ETF) loading condition specified in the NAS Specification [9], as shown in Fig. 5(a) and (b), respectively. For the ITF and the ETF loading conditions, two identical bearing

Table 1

Measured specimen dimensions and experimental ultimate loads for flanges unfastened under ITF loading condition.

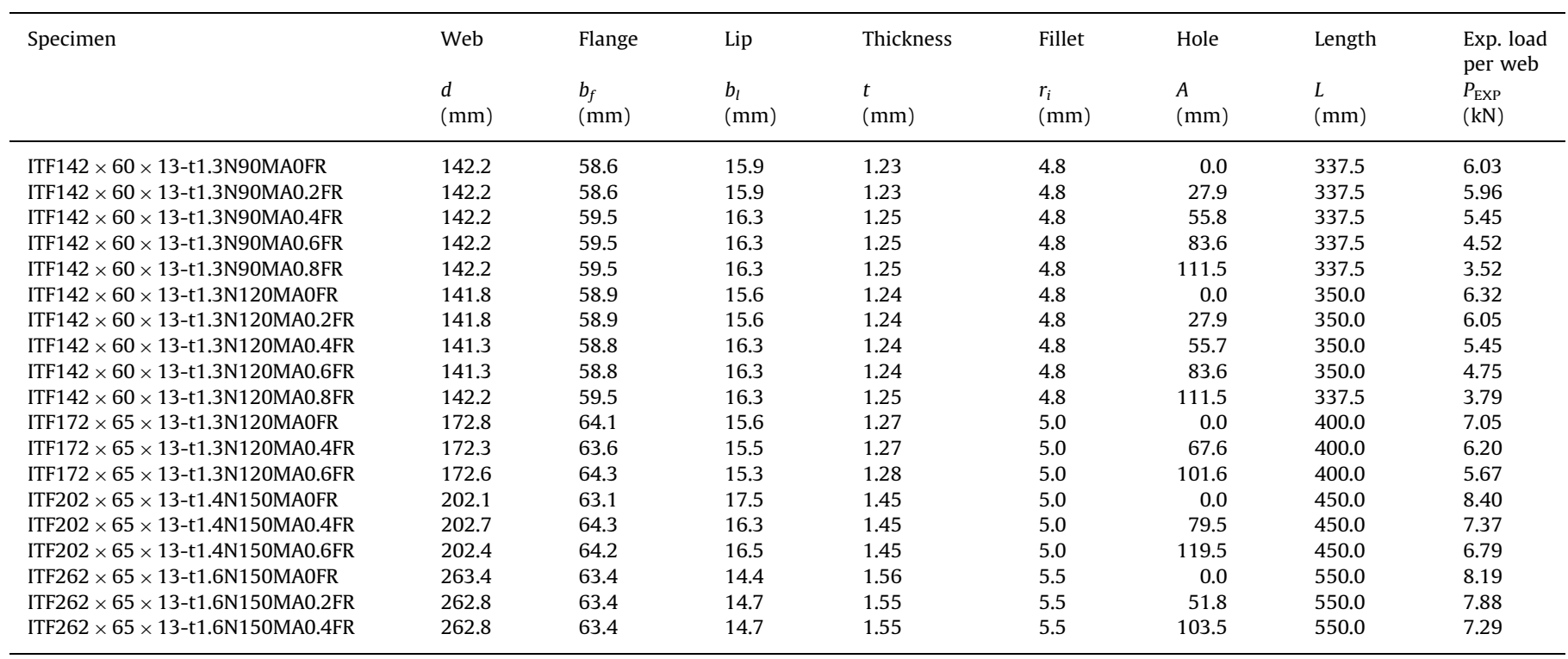


Table 2

Measured specimen dimensions and experimental ultimate loads for flanges fastened under ITF loading condition.

\begin{tabular}{|c|c|c|c|c|c|c|c|c|}
\hline \multirow[t]{2}{*}{ Specimen } & Web & Flange & Lip & Thickness & Fillet & Hole & Length & $\begin{array}{l}\text { Exp. load } \\
\text { per web }\end{array}$ \\
\hline & $\begin{array}{l}d \\
(\mathrm{~mm})\end{array}$ & $\begin{array}{l}b_{f} \\
(\mathrm{~mm})\end{array}$ & $\begin{array}{l}b_{l} \\
(\mathrm{~mm})\end{array}$ & $\begin{array}{l}t \\
(\mathrm{~mm})\end{array}$ & $\begin{array}{l}r_{i} \\
(\mathrm{~mm})\end{array}$ & $\begin{array}{l}A \\
(\mathrm{~mm})\end{array}$ & $\begin{array}{l}L \\
(\mathrm{~mm})\end{array}$ & $\begin{array}{l}P_{\text {EXP }} \\
(\mathrm{kN})\end{array}$ \\
\hline ITF142 $\times 60 \times 13-t 1.3$ N90MA0FX & 142.2 & 58.6 & 15.9 & 1.23 & 4.8 & 0.0 & 337.5 & 8.97 \\
\hline ITF142 × $60 \times 13$-t1.3N90MA0.2FX & 142.2 & 58.6 & 15.9 & 1.23 & 4.8 & 27.9 & 337.5 & 8.96 \\
\hline ITF142 × $60 \times 13-\mathrm{t} 1.3 \mathrm{~N} 90 \mathrm{MA0.4FX}$ & 142.2 & 59.5 & 16.3 & 1.25 & 4.8 & 55.8 & 337.5 & 7.75 \\
\hline ITF142 × $60 \times 13-t 1.3 N 90 M A 0.6 F X$ & 142.2 & 59.5 & 16.3 & 1.25 & 4.8 & 83.6 & 337.5 & 6.64 \\
\hline ITF142 × $60 \times 13-\mathrm{t} 1.3 \mathrm{~N} 90 \mathrm{MA0.8FX}$ & 142.2 & 59.5 & 16.3 & 1.25 & 4.8 & 111.5 & 337.5 & 5.55 \\
\hline ITF142 × $60 \times 13-t 1.3 N 120 M A 0 F X$ & 141.8 & 58.9 & 15.6 & 1.24 & 4.8 & 0.0 & 350.0 & 9.44 \\
\hline ITF142 $\times 60 \times 13-\mathrm{t} 1.3 \mathrm{~N} 120 \mathrm{MA0} .2 \mathrm{FX}$ & 141.8 & 58.9 & 15.6 & 1.24 & 4.8 & 27.9 & 350.0 & 9.26 \\
\hline ITF142 × $60 \times 13-\mathrm{t} 1.3 \mathrm{~N} 120 \mathrm{MA0.4FX}$ & 141.3 & 58.8 & 16.3 & 1.24 & 4.8 & 55.7 & 350.0 & 8.19 \\
\hline ITF142 × $60 \times 13-\mathrm{t} 1.3 \mathrm{~N} 120 \mathrm{MA0} .6 \mathrm{FX}$ & 141.3 & 58.8 & 16.3 & 1.24 & 4.8 & 83.6 & 350.0 & 7.06 \\
\hline ITF142 $\times 60 \times 13-\mathrm{t} 1.3 \mathrm{~N} 120 \mathrm{MA0} .8 \mathrm{FX}$ & 142.2 & 59.5 & 16.3 & 1.25 & 4.8 & 111.5 & 337.5 & 5.94 \\
\hline ITF172 × $65 \times 13-\mathrm{t} 1.3 \mathrm{~N} 120 \mathrm{MAOFX}$ & 172.8 & 64.1 & 15.6 & 1.27 & 5.0 & 0.0 & 400.0 & 10.72 \\
\hline ITF172 $\times 65 \times 13-t 1.3 N 120 M A 0.4 F X$ & 172.3 & 63.6 & 15.5 & 1.27 & 5.0 & 67.6 & 400.0 & 9.31 \\
\hline ITF172 × $65 \times 13-\mathrm{t} 1.3 \mathrm{~N} 120 \mathrm{MA0} .6 \mathrm{FX}$ & 172.6 & 64.3 & 15.3 & 1.28 & 5.0 & 101.6 & 400.0 & 7.87 \\
\hline ITF202 $\times 65 \times 13-\mathrm{t} 1.4 \mathrm{~N} 150 \mathrm{MAOFX}$ & 202.1 & 63.1 & 17.5 & 1.45 & 5.0 & 0.0 & 450.0 & 13.51 \\
\hline ITF202 $\times 65 \times 13-\mathrm{t} 1.4 \mathrm{~N} 150 \mathrm{MA0} .4 \mathrm{FX}$ & 202.7 & 64.3 & 16.3 & 1.45 & 5.0 & 79.5 & 450.0 & 11.42 \\
\hline ITF202 × $65 \times 13-\mathrm{t} 1.4 \mathrm{~N} 150 \mathrm{MA0} .6 \mathrm{FX}$ & 202.4 & 64.2 & 16.5 & 1.45 & 5.0 & 119.5 & 450.0 & 10.10 \\
\hline ITF262 × $65 \times 13$-t1.6N150MA0FX & 263.4 & 63.4 & 14.4 & 1.56 & 5.5 & 0.0 & 550.0 & 12.78 \\
\hline ITF262 $\times 65 \times 13-\mathrm{t} 1.6 \mathrm{~N} 150 \mathrm{MA0} .2 \mathrm{FX}$ & 262.8 & 63.4 & 14.7 & 1.55 & 5.5 & 51.8 & 550.0 & 12.41 \\
\hline ITF262 × $65 \times 13-\mathrm{t} 1.6 \mathrm{~N} 150 \mathrm{MA0.4FX}$ & 262.8 & 63.4 & 14.7 & 1.55 & 5.5 & 103.5 & 550.0 & 11.31 \\
\hline
\end{tabular}

Note: $1 \mathrm{kip}=4.45 \mathrm{kN}$.

Table 3

Measured specimen dimensions and experimental ultimate loads for flanges unfastened under ETF loading condition.

\begin{tabular}{|c|c|c|c|c|c|c|c|c|}
\hline \multirow[t]{2}{*}{ Specimen } & Web & Flange & Lip & Thickness & Fillet & Hole & Length & $\begin{array}{l}\text { Exp. load } \\
\text { per web }\end{array}$ \\
\hline & $\begin{array}{l}d \\
(\mathrm{~mm})\end{array}$ & $\begin{array}{l}b_{f} \\
(\mathrm{~mm})\end{array}$ & $\begin{array}{l}b_{l} \\
(\mathrm{~mm})\end{array}$ & $\begin{array}{l}t \\
(\mathrm{~mm})\end{array}$ & $\begin{array}{l}r_{i} \\
(\mathrm{~mm})\end{array}$ & $\begin{array}{l}a \\
(\mathrm{~mm})\end{array}$ & $\begin{array}{l}L \\
(\mathrm{~mm})\end{array}$ & $\begin{array}{l}P_{\text {EXP }} \\
(\mathrm{kN})\end{array}$ \\
\hline ETF142 × $60 \times 13-\mathrm{t} 1.3 \mathrm{~N} 90 \mathrm{MAOFR}$ & 142.2 & 58.6 & 15.9 & 1.23 & 4.8 & 0.0 & 337.5 & 2.21 \\
\hline ETF142 $\times 60 \times 13-\mathrm{t} 1.3 \mathrm{~N} 90 \mathrm{MA0.2FR}$ & 142.2 & 58.6 & 15.9 & 1.23 & 4.8 & 27.9 & 337.5 & 1.98 \\
\hline ETF142 × $60 \times 13-\mathrm{t} 1.3 \mathrm{~N} 90 \mathrm{MA0.4FR}$ & 142.2 & 59.5 & 16.3 & 1.25 & 4.8 & 55.8 & 337.5 & 1.62 \\
\hline ETF142 $\times 60 \times 13-t 1.3$ N90MA0.6FR & 142.2 & 59.5 & 16.3 & 1.25 & 4.8 & 83.6 & 337.5 & 1.32 \\
\hline ETF142 $\times 60 \times 13-\mathrm{t} 1.3 \mathrm{~N} 120 \mathrm{MAOFR}$ & 141.8 & 58.9 & 15.6 & 1.24 & 4.8 & 0.0 & 350.0 & 2.35 \\
\hline ETF142 $\times 60 \times 13-t 1.3 N 120 M A 0.2 F R$ & 141.8 & 58.9 & 15.6 & 1.24 & 4.8 & 27.9 & 350.0 & 1.95 \\
\hline ETF142 $\times 60 \times 13-t 1.3 N 120 M A 0.4 F R$ & 141.3 & 58.8 & 16.3 & 1.24 & 4.8 & 55.7 & 350.0 & 1.78 \\
\hline ETF142 $\times 60 \times 13-t 1.3 N 120 M A 0.6 F R$ & 141.3 & 58.8 & 16.3 & 1.24 & 4.8 & 83.6 & 350.0 & 1.49 \\
\hline ETF172 $\times 65 \times 13-\mathrm{t} 1.3 \mathrm{~N} 120 \mathrm{MAOFR}$ & 172.8 & 64.1 & 15.6 & 1.27 & 5.0 & 0.0 & 400.0 & 2.37 \\
\hline ETF172 $\times 65 \times 13-t 1.3 N 120 M A 0.4 F R$ & 172.3 & 63.6 & 15.5 & 1.27 & 5.0 & 67.6 & 400.0 & 1.70 \\
\hline ETF172 $\times 65 \times 13-\mathrm{t} 1.3 \mathrm{~N} 120 \mathrm{MA0.6FR}$ & 172.6 & 64.3 & 15.3 & 1.28 & 5.0 & 101.6 & 400.0 & 1.36 \\
\hline ETF202 $\times 65 \times 13-\mathrm{t} 1.4$ N120MA0FR & 202.1 & 63.1 & 17.5 & 1.45 & 5.0 & 0.0 & 425.0 & 2.70 \\
\hline ETF202 $\times 65 \times 13-t 1.4$ N120MA0.2FR & 202.7 & 64.3 & 16.3 & 1.45 & 5.0 & 39.8 & 425.0 & 2.41 \\
\hline ETF202 $\times 65 \times 13-t 1.4$ N120MA0.4FR & 202.4 & 64.2 & 16.5 & 1.45 & 5.0 & 79.5 & 425.0 & 1.88 \\
\hline ETF202 $\times 65 \times 13-\mathrm{t} 1.4$ N150MA0FR & 202.1 & 63.1 & 17.5 & 1.45 & 5.0 & 0.0 & 450.0 & 2.84 \\
\hline ETF202 $\times 65 \times 13-t 1.4$ N150MA0.4FR & 202.7 & 64.3 & 16.3 & 1.45 & 5.0 & 79.5 & 450.0 & 2.19 \\
\hline ETF202 $\times 65 \times 13-t 1.4$ N150MA0.6FR & 202.4 & 64.2 & 16.5 & 1.45 & 5.0 & 119.5 & 450.0 & 1.77 \\
\hline ETF262 $\times 65 \times 13$-t1.6N120MA0FR & 263.4 & 63.4 & 14.4 & 1.56 & 5.5 & 0.0 & 525.0 & 2.55 \\
\hline ETF262 $\times 65 \times 13-\mathrm{t} 1.6 \mathrm{~N} 120 \mathrm{MA0.2FR}$ & 263.4 & 63.4 & 14.4 & 1.56 & 5.5 & 51.8 & 525.0 & 2.29 \\
\hline ETF262 $\times 65 \times 13-t 1.6 N 120 \mathrm{MA0.4FR}$ & 262.8 & 63.4 & 14.7 & 1.55 & 5.5 & 103.4 & 525.0 & 1.77 \\
\hline ETF262 × $65 \times 13-t 1.6 N 150 M A 0 F R$ & 263.4 & 63.4 & 14.4 & 1.56 & 5.5 & 0.0 & 550.0 & 2.82 \\
\hline ETF262 $\times 65 \times 13-\mathrm{t} 1.6 \mathrm{~N} 150 \mathrm{MA} 0.4 \mathrm{FR}$ & 262.8 & 63.4 & 14.7 & 1.55 & 5.5 & 103.4 & 550.0 & 2.04 \\
\hline
\end{tabular}

Note: $1 \mathrm{kip}=4.45 \mathrm{kN}$.

plates of the same width were positioned at the end and at the mid-length of each specimen, respectively. Hinge supports were simulated by two half rounds in the line of action of the force. A servo-controlled Tinius-Olsen testing machine was used to apply a concentrated compressive force to the test specimens. Displacement control was used to drive the hydraulic actuator at a constant speed of $0.05 \mathrm{~mm} / \mathrm{min}$ for all the test specimens. The load or reaction force was applied by means of bearing plates. The bearing plates were fabricated using a high strength steel. All the bearing plates were machined to specified dimensions, and the thickness was $25 \mathrm{~mm}$. The bearing plates were designed to act across the full flange widths of the channel sections. The flanges of the channel section specimens were unfastened and fastened to the bearing plates during testing as shown in Fig. 6(a) and (b), respectively. In the flanges fastened test setup, the flanges were bolted to the bearing plate. Photographs of the ITF and ETF test are shown in Fig. 7(a), Fig. 8(a), Fig. 9(a), and Fig. 10(a) with flanges unfastened and fastened, respectively.

\subsection{Test results}

A total of 38 specimens were tested under the interior-twoflange (ITF) loading condition and 44 specimens were tested under end-two-flange (ETF). The experimental ultimate web crippling loads per web $\left(P_{\mathrm{EXP}}\right)$ are given in Tables $1-4$. Fig. 11 and Fig. 12 shows the typical failure mode of web crippling of the 
Table 4

Measured specimen dimensions and experimental ultimate loads for flanges fastened under ETF loading condition.

\begin{tabular}{|c|c|c|c|c|c|c|c|c|}
\hline \multirow[t]{2}{*}{ Specimen } & \multirow{2}{*}{$\begin{array}{l}\text { Web } \\
d \\
(\mathrm{~mm})\end{array}$} & \multirow{2}{*}{$\begin{array}{l}\text { Flange } \\
b_{f} \\
(\mathrm{~mm})\end{array}$} & \multirow{2}{*}{$\begin{array}{l}\text { Lip } \\
b_{l} \\
(\mathrm{~mm})\end{array}$} & \multirow{2}{*}{$\begin{array}{l}\text { Thickness } \\
t \\
(\mathrm{~mm})\end{array}$} & \multirow{2}{*}{$\begin{array}{l}\text { Fillet } \\
r_{i} \\
(\mathrm{~mm})\end{array}$} & \multirow{2}{*}{$\begin{array}{l}\text { Hole } \\
a \\
(\mathrm{~mm})\end{array}$} & \multirow{2}{*}{$\begin{array}{l}\text { Length } \\
L \\
(\mathrm{~mm})\end{array}$} & \multirow{2}{*}{$\begin{array}{l}\text { Exp. load } \\
\text { per web } \\
P_{\text {EXP }} \\
(\mathrm{kN})\end{array}$} \\
\hline & & & & & & & & \\
\hline ETF142 × $60 \times 13-\mathrm{t} 1.3 \mathrm{~N} 90 \mathrm{MAOFX}$ & 142.2 & 58.6 & 15.9 & 1.23 & 4.8 & 0.0 & 337.5 & 3.75 \\
\hline ETF142 $\times 60 \times 13-t 1.3 N 90 M A 0.2 F X$ & 142.2 & 58.6 & 15.9 & 1.23 & 4.8 & 27.9 & 337.5 & 3.16 \\
\hline ETF142 $\times 60 \times 13-t 1.3 N 90 M A 0.4 F X$ & 142.2 & 59.5 & 16.3 & 1.25 & 4.8 & 55.8 & 337.5 & 2.79 \\
\hline ETF142 $\times 60 \times 13-t 1.3$ N90MA0.6FX & 142.2 & 59.5 & 16.3 & 1.25 & 4.8 & 83.6 & 337.5 & 2.55 \\
\hline ETF142 × $60 \times 13-t 1.3 N 120 M A 0 F X$ & 141.8 & 58.9 & 15.6 & 1.24 & 4.8 & 0.0 & 350.0 & 4.06 \\
\hline ETF142 $\times 60 \times 13-\mathrm{t} 1.3 \mathrm{~N} 120 \mathrm{MA0} .2 \mathrm{FX}$ & 141.8 & 58.9 & 15.6 & 1.24 & 4.8 & 27.9 & 350.0 & 3.58 \\
\hline ETF142 × $60 \times 13-\mathrm{t} 1.3 \mathrm{~N} 120 \mathrm{MA0} .4 \mathrm{FX}$ & 141.3 & 58.8 & 16.3 & 1.24 & 4.8 & 55.7 & 350.0 & 3.44 \\
\hline ETF142 $\times 60 \times 13-\mathrm{t} 1.3 \mathrm{~N} 120 \mathrm{MA0} .6 \mathrm{FX}$ & 141.3 & 58.8 & 16.3 & 1.24 & 4.8 & 83.6 & 350.0 & 2.94 \\
\hline ETF172 × $65 \times 13-\mathrm{t} 1.3 \mathrm{~N} 120 \mathrm{MAOFX}$ & 172.8 & 64.1 & 15.6 & 1.27 & 5.0 & 0.0 & 400.0 & 4.16 \\
\hline ETF172 × $65 \times 13-\mathrm{t} 1.3 \mathrm{~N} 120 \mathrm{MA0} .4 \mathrm{FX}$ & 172.3 & 63.6 & 15.5 & 1.27 & 5.0 & 67.6 & 400.0 & 3.48 \\
\hline ETF172 $\times 65 \times 13-\mathrm{t} 1.3 \mathrm{~N} 120 \mathrm{MA0} .6 \mathrm{FX}$ & 172.6 & 64.3 & 15.3 & 1.28 & 5.0 & 101.6 & 400.0 & 3.00 \\
\hline ETF202 × $65 \times 13-\mathrm{t} 1.4 \mathrm{~N} 120 \mathrm{MAOFX}$ & 202.1 & 63.1 & 17.5 & 1.45 & 5.0 & 0.0 & 425.0 & 5.24 \\
\hline ETF202 × $65 \times 13-\mathrm{t} 1.4 \mathrm{~N} 120 \mathrm{MA0.2FX}$ & 202.7 & 64.3 & 16.3 & 1.45 & 5.0 & 39.8 & 425.0 & 4.88 \\
\hline ETF202 $\times 65 \times 13-\mathrm{t} 1.4 \mathrm{~N} 120 \mathrm{MA0} .4 \mathrm{FX}$ & 202.4 & 64.2 & 16.5 & 1.45 & 5.0 & 79.5 & 425.0 & 4.27 \\
\hline ETF202 × $65 \times 13-\mathrm{t} 1.4 \mathrm{~N} 150 \mathrm{MA0FX}$ & 202.1 & 63.1 & 17.5 & 1.45 & 5.0 & 0.0 & 450.0 & 5.82 \\
\hline ETF202 $\times 65 \times 13-\mathrm{t} 1.4 \mathrm{~N} 150 \mathrm{MA0.4FX}$ & 202.7 & 64.3 & 16.3 & 1.45 & 5.0 & 79.5 & 450.0 & 4.73 \\
\hline ETF202 $\times 65 \times 13-\mathrm{t} 1.4 \mathrm{~N} 150 \mathrm{MA0.6FX}$ & 202.4 & 64.2 & 16.5 & 1.45 & 5.0 & 119.5 & 450.0 & 4.24 \\
\hline ETF262 × $65 \times 13-\mathrm{t} 1.6 \mathrm{~N} 120 \mathrm{MA0FX}$ & 263.4 & 63.4 & 14.4 & 1.56 & 5.5 & 0.0 & 525.0 & 5.06 \\
\hline ETF262 $\times 65 \times 13-\mathrm{t} 1.6 \mathrm{~N} 120 \mathrm{MA0} .2 \mathrm{FX}$ & 263.4 & 63.4 & 14.4 & 1.56 & 5.5 & 51.8 & 525.0 & 4.60 \\
\hline ETF262 $\times 65 \times 13-\mathrm{t} 1.6 \mathrm{~N} 120 \mathrm{MA0} .4 \mathrm{FX}$ & 262.8 & 63.4 & 14.7 & 1.55 & 5.5 & 103.4 & 525.0 & 3.89 \\
\hline ETF262 × $65 \times 13-\mathrm{t} 1.6 \mathrm{~N} 150 \mathrm{MA0FX}$ & 263.4 & 63.4 & 14.4 & 1.56 & 5.5 & 0.0 & 550.0 & 5.37 \\
\hline ETF262 $\times 65 \times 13-\mathrm{t} 1.6 \mathrm{~N} 150 \mathrm{MA0} .4 \mathrm{FX}$ & 262.8 & 63.4 & 14.7 & 1.55 & 5.5 & 103.4 & 550.0 & 4.25 \\
\hline
\end{tabular}

Note: $1 \mathrm{kip}=4.45 \mathrm{kN}$.

Table 5

Material properties of specimens.

\begin{tabular}{llll}
\hline Section & $\sigma_{0.2}(\mathrm{MPa})$ & $\sigma_{u}(\mathrm{MPa})$ & $\varepsilon_{f}(\%)$ \\
\hline $142 \times 60 \times 13 \times 1.3$ & 455 & 532 & 23 \\
$172 \times 65 \times 16 \times 1.3$ & 534 & 566 & 10 \\
$202 \times 65 \times 13 \times 1.4$ & 513 & 552 & 11 \\
$262 \times 65 \times 13 \times 1.6$ & 525 & 546 & 10 \\
$302 \times 88 \times 18 \times 2.0$ & 483 & 523 & 11 \\
\hline
\end{tabular}

specimens under ITF and ETF loading conditions with flanges unfastened and fastened, respectively. Typical examples of the load-deflection curve obtained from a specimen both without and with web holes, and the comparisons with the numerical results, are shown in Fig. 13 and Fig. 14.

\section{Numerical investigation}

\subsection{General}

The non-linear elasto-plastic general purpose finite element program ANSYS [8] was used to simulate the channel sections with and without holes subjected to web crippling. The bearing plates, the channel section with circular holes and the interfaces between the bearing plates and the channel section have been modelled. In the finite element model, the measured cross-section dimensions and the material properties obtained from the tests were used. The model was based on the centreline dimensions of the cross-sections. Specific modelling issues are described in the following subsection.

\subsection{Geometry and material properties}

One-quarter of the test set-up was modelled using symmetry about both the vertical transverse and horizontal planes is shown in Fig. 7(b), Fig. 8(b), Fig. 9(b), and Fig. 10(b). Contact surfaces are

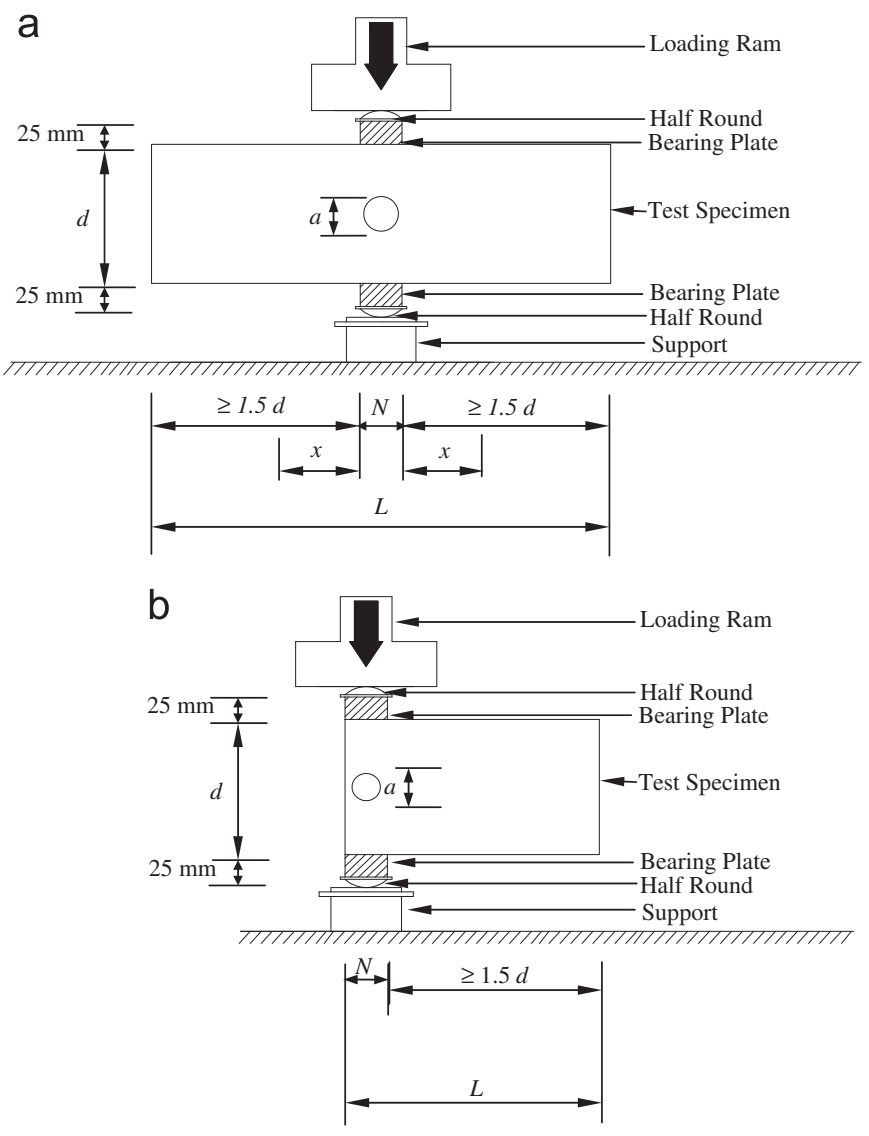

Fig. 5. Schematic view test set-up (front view): (a) ITF loading condition and (b) ETF loading condition.

defined between the bearing plate and the cold-formed steel section.

The value of Young's modulus was $203 \mathrm{kN} / \mathrm{mm}^{2}$ and Poisson's ratio was 0.3 . The material non-linearity was incorporated in the 


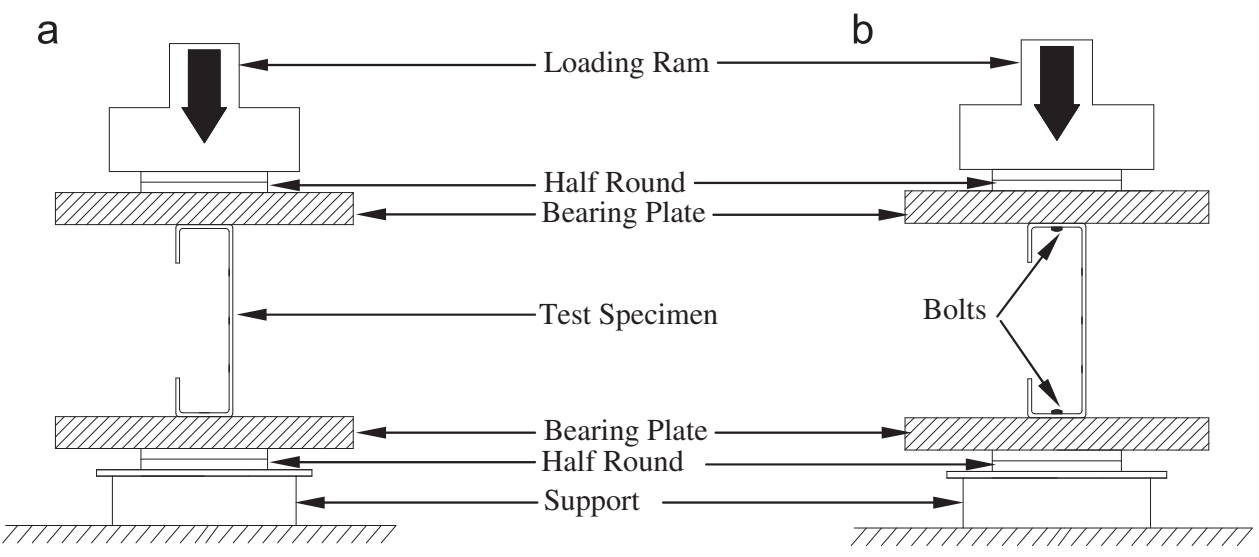

Fig. 6. Schematic view of test set-up (End view): (a) Unfastened flanges and (b) Fastened flanges.

a
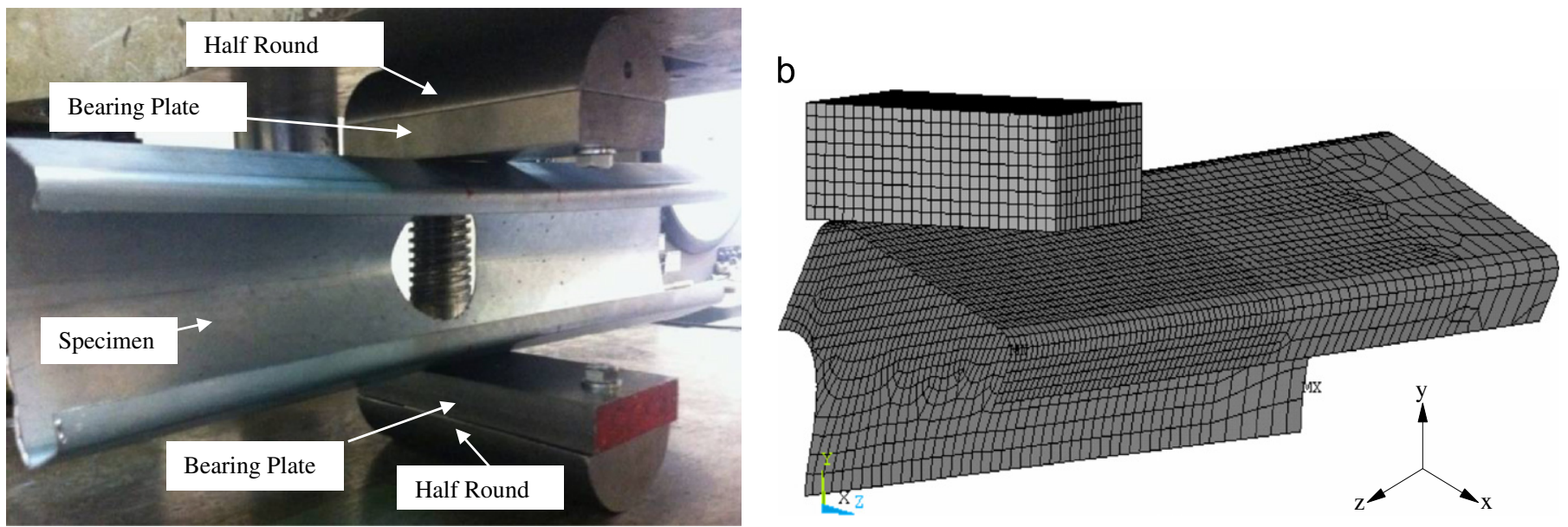

Fig. 7. Comparison of experiment and finite element analysis for flanges unfastened under ITF loading condition: (a) Experimental and (b) FEA.

a

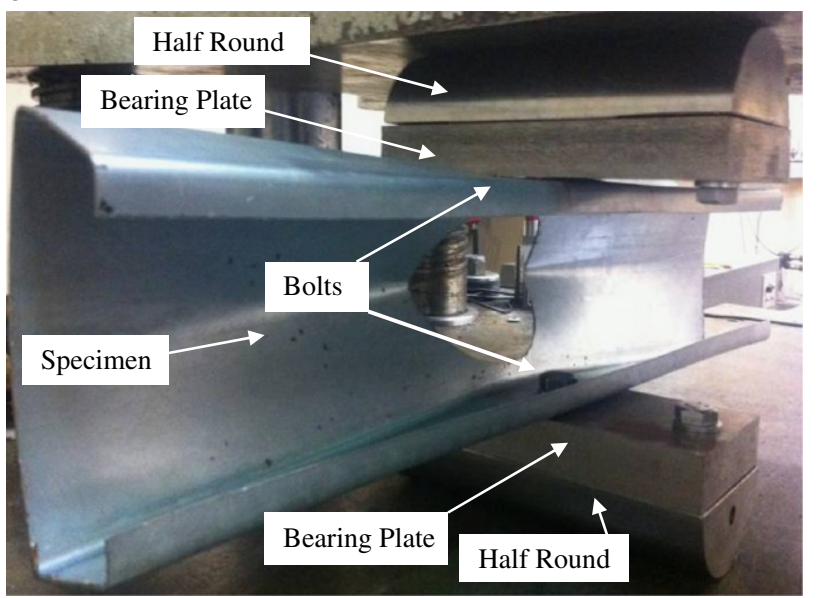

b

Fig. 8. Comparison of experiment and finite element analysis for flanges fastened under ITF loading condition: (a) Experimental and (b) FEA.

finite element model by specifying 'true' values of stresses and strains. The plasticity of the material was determined by a mathematical model, known as the incremental plasticity model; the true stress $\left(\sigma_{\text {true }}\right)$ and plastic true strain $\left(\varepsilon_{\text {true }}\right)$ were as per the specified method in the ANSYS manual (2011).

\subsection{Element type and mesh sensitivity}

Fig. 7(b), Fig. 8(b), Fig. 9(b), and Fig. 10(b) shows details of a typical finite element mesh of the channel section and the bearing plate. The effect of different element sizes in the cross-section of 
a

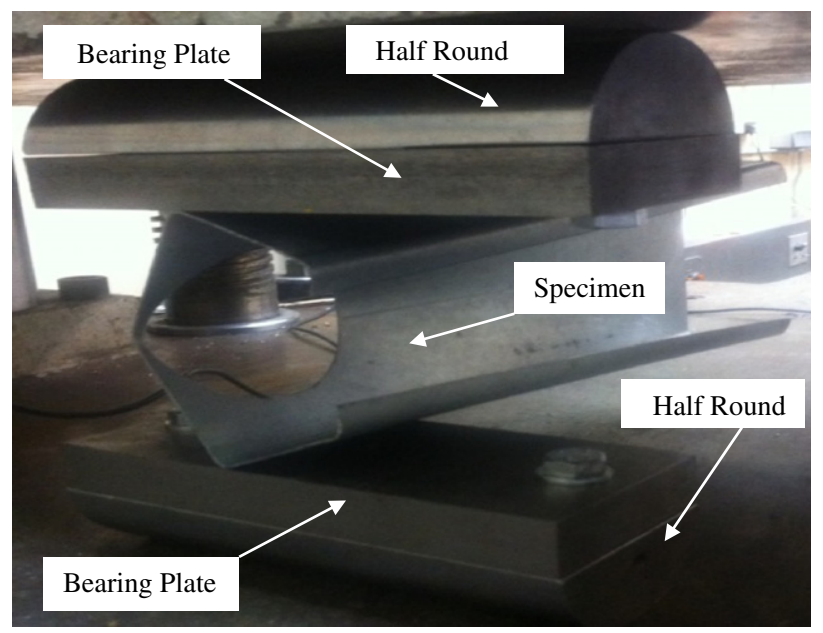

b

Fig. 9. Comparison of experiment and finite element analysis for flanges unfastened under ETF loading condition: (a) Experimental and (b) FEA.

a

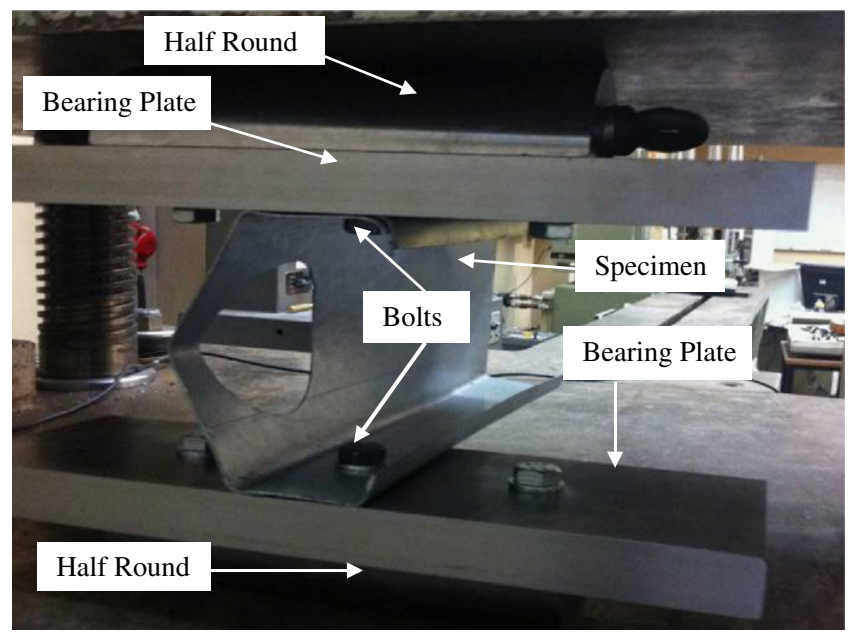

b

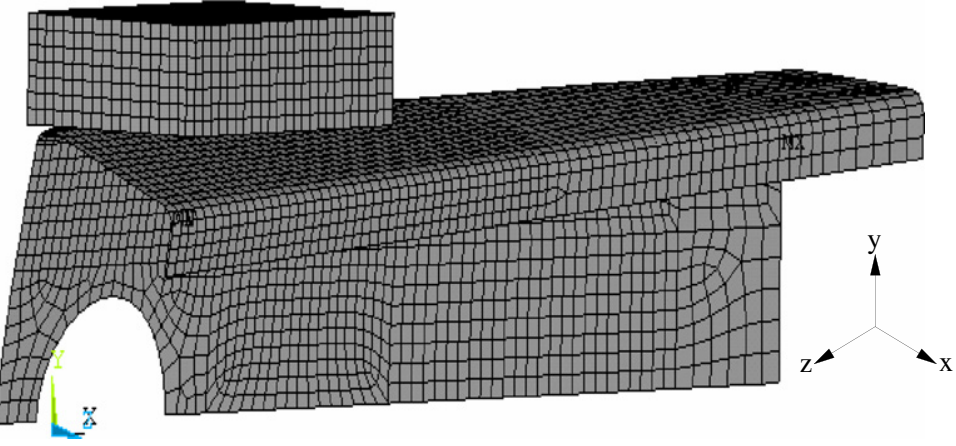

Fig. 10. Comparison of experiment and finite element analysis for flanges fastened under ETF loading condition: (a) Experimental and (b) FEA.

the channel section was investigated to provide both accurate results and reduced computation time. Depending on the size of the section, the finite element mesh sizes ranged from $3 \times 3 \mathrm{~mm}$ (length by width) to $5 \times 5 \mathrm{~mm}$.

It is necessary to finely mesh the corners of the section due to the transfer of stress from the flange to the web. Nine elements were used around the inside corner radius that forms the bend between the flange and web. Three elements were used at the rounded corners between the flange and lip of the section. The number of elements was chosen so that the aspect ratio of the elements was as close to one as possible. Where holes were modelled, finer mesh sizes were used around the web holes. Mesh sensitivity analyses were performed to verify the number of elements.

The channel sections were modelled using the 4-noded shell element SHELL181. The bearing plates were modelled using the eight-noded solid element SOLID45. CONTACT173 and TARGET170 elements were used for modelling contact between the flanges and the load bearing plates.

\subsection{Loading and boundary conditions}

The nodes of the cold-formed steel section and the bearing plate were restrained to represent the vertical and horizontal symmetry condition. The interface between the bearing plate and the cold-formed steel section were modelled using the surface-tosurface contact option. The bearing plate was the target surface, while the cold-formed steel section was the contact surface. The two contact surfaces were not allowed to penetrate each other.

The vertical load applied to the channel sections in the laboratory tests was modelled using displacement control method; an imposed displacement is applied to the nodes of the top bearing plate where the vertical load is applied. The top bearing plate was restrained against all degrees of freedom, except for the translational degree of freedom in the y-direction. In the flanges fastened condition, the node coupling method was used in the region where the flanges connected to the bearing plates. The nodes were coupled together in all degrees of freedom.

\subsection{Verification of finite element model}

In order to validate the finite element model, the experimental failure loads were compared against the failure load predicted by the finite element analysis. The main objective of this comparison was to verify and check the accuracy of the finite element model. A comparison of the test results $\left(P_{\mathrm{EXP}}\right)$ with the numerical results $\left(P_{\mathrm{FEA}}\right)$ of web crippling strengths per web is shown in Table 6, Table 7, Table 8 and Table 9. Load-deflection curves comparing 
a

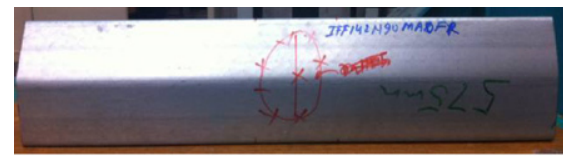

A0

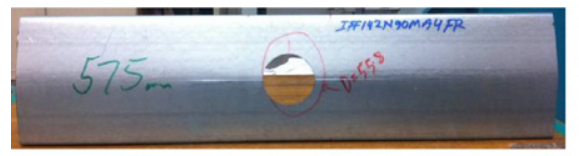

A0.4

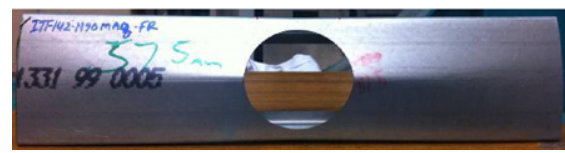

A0.8

b

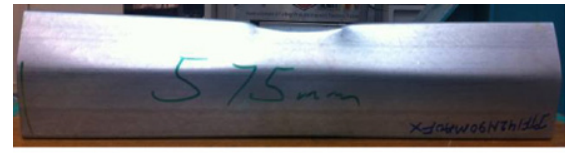

A0

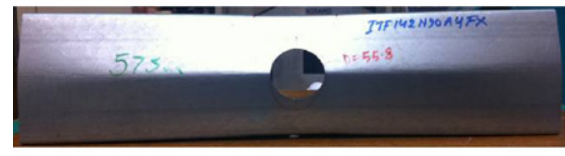

A0.4

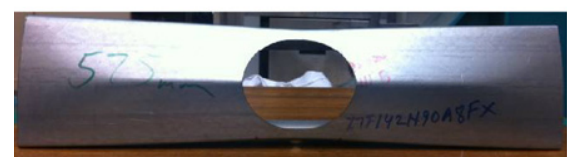

A0.8

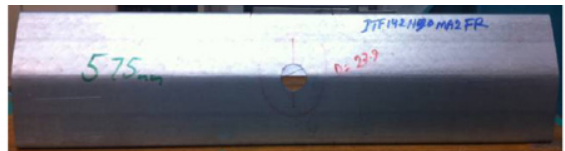

A 0.2

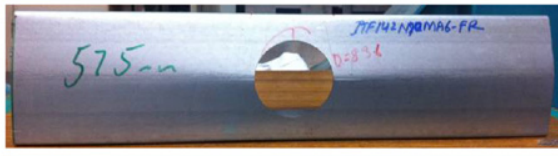

A0.6

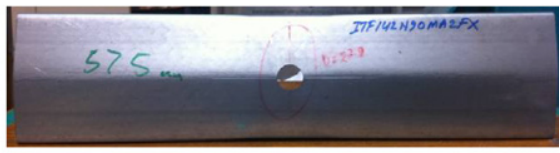

A 0.2

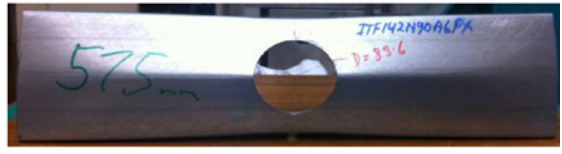

A0.6

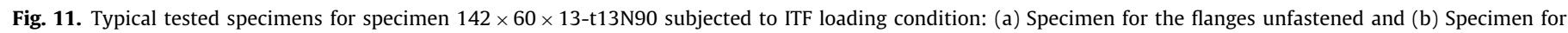
flanges fastened.

a

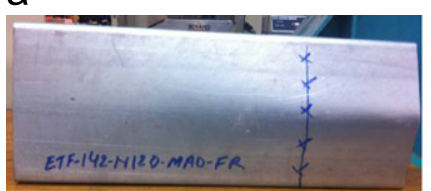

A0

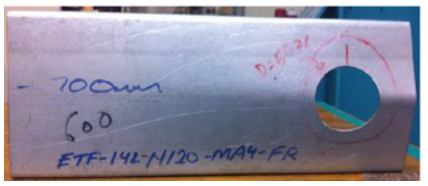

A0.4

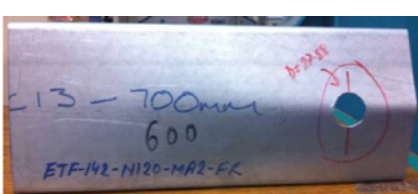

A 0.2

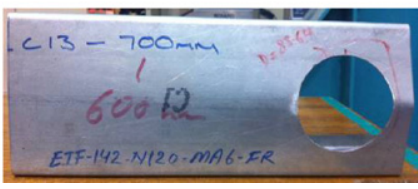

A 0.6

b

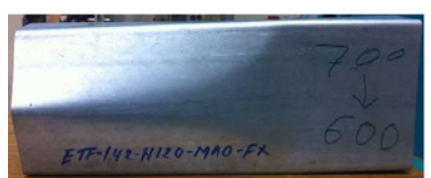

A0

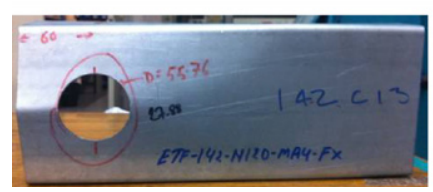

A0.4

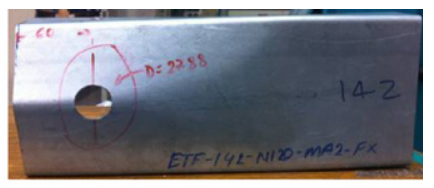

A 0.2

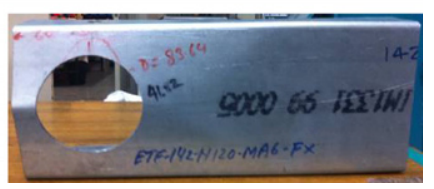

A0.6

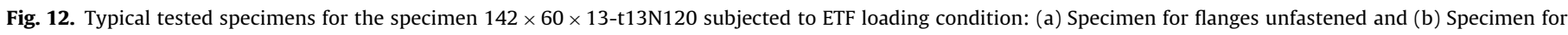
flanges fastened.

the experimental results and the finite element results are shown in Fig. 13 and Fig. 14 covering the cases of both with and without the web holes. It can be seen that good agreement has been achieved between both results for all specimens.

For the ITF loading condition, the mean value of the $P_{\mathrm{EXP}} / P_{\mathrm{FEA}}$ ratio is 0.99 and 0.98 with the corresponding coefficient of variation (COV) of 0.02 and 0.01 for the flanges unfastened and fastened conditions, respectively. A maximum difference of $5 \%$ and $4 \%$ was observed between the experimental and the numerical results for the specimen ITF142 $\times 60 \times 13$-t1.3N90MA0.8FR and ITF142 $\times 60 \times 13$-t13MN90A0.8FX, respectively.
For the ETF loading condition, the mean value of the $P_{\mathrm{EXP}} / P_{\mathrm{FEA}}$ ratio is 0.94 and 0.95 with the corresponding coefficient of variation (COV) of 0.05 and 0.05 for the flanges unfastened and fastened conditions, respectively. A maximum difference of $15 \%$ and $15 \%$ was observed between the experimental and the numerical results for the specimen ETF142 $\times 60 \times 13$-t1.3N120MA0.2FR and ETF142 × $60 \times 13$-t1.3N120MA0.2FX, respectively.

The web crippling failure mode observed from the tests has also been verified by the finite element model for the ITF and ETF loading conditions with flanges unfastened and fastened, as shown in Fig. 7, Fig. 8, Fig. 9 and Fig. 10, respectively. It is shown 

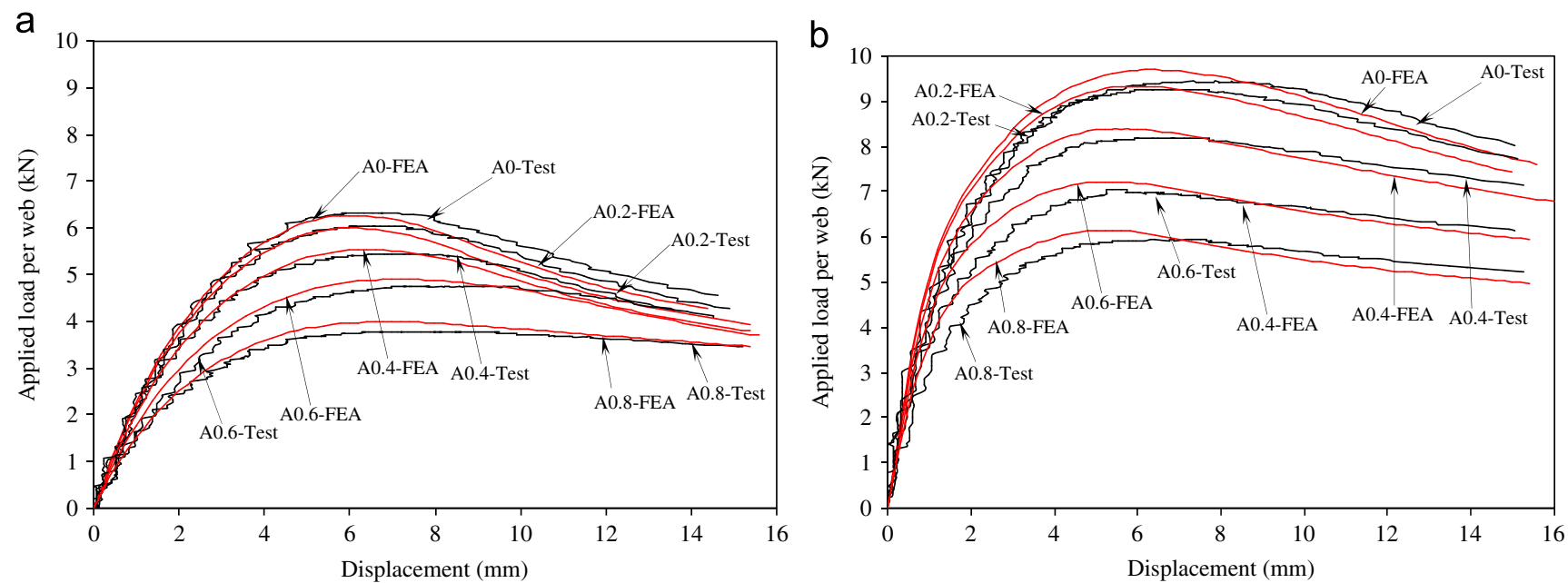

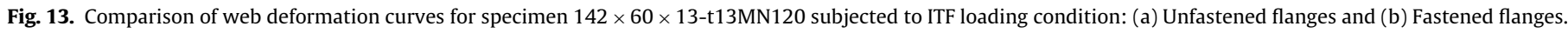
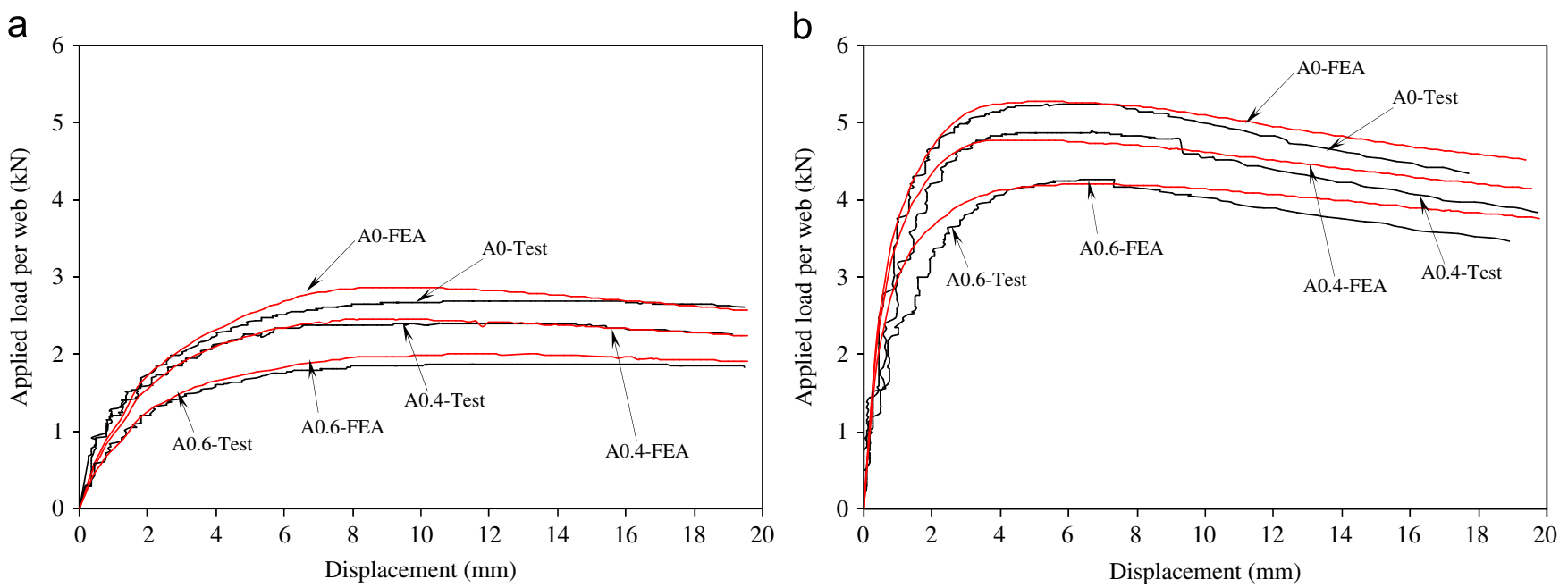

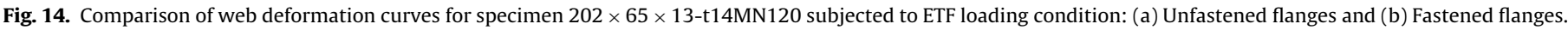

Table 6

Comparison of web crippling strength predicted from finite element analysis with experiment results for unfastened flanges under ITF loading condition.

\begin{tabular}{|c|c|c|c|c|c|}
\hline Specimen & $\begin{array}{l}\text { Web } \\
\text { slenderness } \\
h / t\end{array}$ & $\begin{array}{l}\text { Hole diameter } \\
\text { ratio } \\
a / h\end{array}$ & $\begin{array}{l}\text { Exp. load per } \\
\text { web } \\
P_{\text {EXP }} \\
(\mathrm{kN})\end{array}$ & $\begin{array}{l}\text { Web crippling strength per } \\
\text { web predicted from FEA } \\
P_{\text {FEA }} \\
(\mathrm{kN})\end{array}$ & $\begin{array}{l}\text { Comparison } \\
P_{\text {EXP }} / P_{\text {FEA }}\end{array}$ \\
\hline ITF142 × $60 \times 13-t 1.3$ N90MA0FR & 113.8 & 0.0 & 6.03 & 6.06 & 1.00 \\
\hline ITF142 × $60 \times 13-\mathrm{t} 1.3 \mathrm{~N} 90 \mathrm{MA0} 0.2 \mathrm{FR}$ & 113.8 & 0.2 & 5.96 & 5.80 & 1.03 \\
\hline ITF142 $\times 60 \times 13-\mathrm{t} 1.3 \mathrm{~N} 90 \mathrm{MA0.4FR}$ & 112.2 & 0.4 & 5.45 & 5.33 & 1.02 \\
\hline ITF142 $\times 60 \times 13-\mathrm{t} 1.3 \mathrm{~N} 90 \mathrm{MA0} .6 \mathrm{FR}$ & 112.2 & 0.6 & 4.52 & 4.65 & 0.97 \\
\hline ITF142 × $60 \times 13-\mathrm{t} 1.3 \mathrm{~N} 90 \mathrm{MA0} 0.8 \mathrm{FR}$ & 112.2 & 0.8 & 3.52 & 3.71 & 0.95 \\
\hline ITF142 × $60 \times 13-\mathrm{t} 1.3 \mathrm{~N} 120 \mathrm{MAOFR}$ & 112.5 & 0.0 & 6.32 & 6.28 & 1.01 \\
\hline ITF142 × $60 \times 13-\mathrm{t} 1.3 \mathrm{~N} 120 \mathrm{MA0} .2 \mathrm{FR}$ & 112.5 & 0.2 & 6.05 & 6.00 & 1.01 \\
\hline ITF142 × $60 \times 13-\mathrm{t} 1.3 \mathrm{~N} 120 \mathrm{MA0} 0.4 \mathrm{FR}$ & 112.4 & 0.4 & 5.45 & 5.54 & 0.98 \\
\hline ITF142 × $60 \times 13-\mathrm{t} 1.3 \mathrm{~N} 120 \mathrm{MA0} .6 \mathrm{FR}$ & 112.4 & 0.6 & 4.75 & 4.90 & 0.97 \\
\hline ITF142 × $60 \times 13-\mathrm{t} 1.3 \mathrm{~N} 120 \mathrm{MA0} 0.8 \mathrm{FR}$ & 112.2 & 0.8 & 3.79 & 4.00 & 0.95 \\
\hline ITF172 $\times 65 \times 13-\mathrm{t} 1.3 \mathrm{~N} 120 \mathrm{MAOFR}$ & 134.5 & 0.0 & 7.05 & 7.17 & 0.98 \\
\hline ITF172 × $65 \times 13-\mathrm{t} 1.3 \mathrm{~N} 120 \mathrm{MA0.4FR}$ & 134.1 & 0.4 & 6.20 & 6.40 & 0.97 \\
\hline ITF172 × $65 \times 13-\mathrm{t} 1.3 \mathrm{~N} 120 \mathrm{MA0} .6 \mathrm{FR}$ & 133.3 & 0.6 & 5.67 & 5.68 & 1.00 \\
\hline ITF202 × $65 \times 13-\mathrm{t} 1.4$ N150MAOFR & 137.4 & 0.0 & 8.40 & 8.52 & 0.99 \\
\hline ITF202 × $65 \times 13-\mathrm{t} 1.4 \mathrm{~N} 150 \mathrm{MA0} .4 \mathrm{FR}$ & 137.8 & 0.4 & 7.37 & 7.56 & 0.97 \\
\hline ITF202 × $65 \times 13-\mathrm{t} 1.4 \mathrm{~N} 150 \mathrm{MA0} .6 \mathrm{FR}$ & 137.6 & 0.6 & 6.79 & 6.80 & 1.00 \\
\hline ITF262 $\times 65 \times 13-\mathrm{t} 1.6 \mathrm{~N} 150 \mathrm{MAOFR}$ & 166.9 & 0.0 & 8.19 & 8.04 & 1.02 \\
\hline ITF262 × $65 \times 13-\mathrm{t} 1.6 \mathrm{~N} 150 \mathrm{MA0} 0.2 \mathrm{FR}$ & 167.5 & 0.2 & 7.88 & 7.78 & 1.01 \\
\hline ITF262 × $65 \times 13-\mathrm{t} 1.6 \mathrm{~N} 150 \mathrm{MA0} .4 \mathrm{FR}$ & 167.5 & 0.4 & 7.29 & 7.26 & 1.00 \\
\hline Mean & & & & & 0.99 \\
\hline COV & & & & & 0.02 \\
\hline
\end{tabular}


Table 7

Comparison of web crippling strength predicted from finite element analysis with experiment results for fastened flanges under ITF loading condition.

\begin{tabular}{|c|c|c|c|c|c|}
\hline Specimen & $\begin{array}{l}\text { Web } \\
\text { slenderness } \\
h / t\end{array}$ & $\begin{array}{l}\text { Hole diameter } \\
\text { ratio } \\
a / h\end{array}$ & $\begin{array}{l}\text { Exp. load per } \\
\text { web } \\
P_{\text {EXP }} \\
(\mathrm{kN})\end{array}$ & $\begin{array}{l}\text { Web crippling strength per } \\
\text { web predicted from FEA } \\
P_{\text {FEA }} \\
(\mathrm{kN})\end{array}$ & $\begin{array}{l}\text { Comparison } \\
P_{\text {EXP }} / P_{\text {FEA }}\end{array}$ \\
\hline ITF142 × $60 \times 13-t 1.3 N 90 M A 0 F X$ & 113.8 & 0.0 & 8.97 & 9.10 & 0.99 \\
\hline ITF142 × $60 \times 13-\mathrm{t} 1.3 \mathrm{~N} 90 \mathrm{MA0.2FX}$ & 113.8 & 0.2 & 8.96 & 9.06 & 0.99 \\
\hline ITF142 × $60 \times 13-t 1.3$ N90MA0.4FX & 112.2 & 0.4 & 7.75 & 8.08 & 0.96 \\
\hline ITF142 $\times 60 \times 13-t 1.3$ N90MA0.6FX & 112.2 & 0.6 & 6.64 & 6.81 & 0.98 \\
\hline ITF142 $\times 60 \times 13-\mathrm{t} 1.3 \mathrm{~N} 90 \mathrm{MA0} .8 \mathrm{FX}$ & 112.2 & 0.8 & 5.55 & 5.72 & 0.97 \\
\hline ITF142 $\times 60 \times 13-t 1.3 N 120 M A 0 F X$ & 112.5 & 0.0 & 9.44 & 9.70 & 0.97 \\
\hline ITF142 × $60 \times 13-\mathrm{t} 1.3 \mathrm{~N} 120 \mathrm{MA0} .2 \mathrm{FX}$ & 112.5 & 0.2 & 9.26 & 9.34 & 0.99 \\
\hline ITF142 × $60 \times 13-\mathrm{t} 1.3 \mathrm{~N} 120 \mathrm{MA0} .4 \mathrm{FX}$ & 112.4 & 0.4 & 8.19 & 8.40 & 0.98 \\
\hline ITF142 × $60 \times 13-\mathrm{t} 1.3 \mathrm{~N} 120 \mathrm{MA0} .6 \mathrm{FX}$ & 112.4 & 0.6 & 7.06 & 7.23 & 0.98 \\
\hline ITF142 × $60 \times 13-\mathrm{t} 1.3 \mathrm{~N} 120 \mathrm{MA0} .8 \mathrm{FX}$ & 112.2 & 0.8 & 5.94 & 6.15 & 0.97 \\
\hline ITF172 × $65 \times 13-t 1.3 N 120 M A 0 F X$ & 134.5 & 0.0 & 10.72 & 11.12 & 0.96 \\
\hline ITF172 × $65 \times 13-\mathrm{t} 1.3 \mathrm{~N} 120 \mathrm{MA0.4FX}$ & 134.1 & 0.4 & 9.31 & 9.62 & 0.97 \\
\hline ITF172 × $65 \times 13-\mathrm{t} 1.3 \mathrm{~N} 120 \mathrm{MA0} .6 \mathrm{FX}$ & 133.3 & 0.6 & 7.87 & 8.12 & 0.97 \\
\hline ITF202 $\times 65 \times 13-\mathrm{t} 1.4 \mathrm{~N} 150 \mathrm{MAOFX}$ & 137.4 & 0.0 & 13.51 & 13.66 & 0.99 \\
\hline ITF202 × $65 \times 13-\mathrm{t} 1.4 \mathrm{~N} 150 \mathrm{MA0} .4 \mathrm{FX}$ & 137.8 & 0.4 & 11.42 & 11.82 & 0.97 \\
\hline ITF202 $\times 65 \times 13-t 1.4$ N150MA0.6FX & 137.6 & 0.6 & 10.10 & 10.10 & 1.00 \\
\hline ITF262 $\times 65 \times 13-\mathrm{t} 1.6 \mathrm{~N} 150 \mathrm{MAOFX}$ & 166.9 & 0.0 & 12.78 & 12.95 & 0.99 \\
\hline ITF262 × $65 \times 13-\mathrm{t} 1.6 \mathrm{~N} 150 \mathrm{MA0} .2 \mathrm{FX}$ & 167.5 & 0.2 & 12.41 & 12.56 & 0.99 \\
\hline ITF262 $\times 65 \times 13-\mathrm{t} 1.6 \mathrm{~N} 150 \mathrm{MA0} 0.4 \mathrm{FX}$ & 167.5 & 0.4 & 11.31 & 11.53 & 0.98 \\
\hline Mean & & & & & 0.98 \\
\hline $\mathrm{COV}$ & & & & & 0.01 \\
\hline
\end{tabular}

Table 8

Comparison of web crippling strength predicted from finite element analysis with experiment results for unfastened flanges under ETF loading condition.

\begin{tabular}{|c|c|c|c|c|c|}
\hline Specimen & $\begin{array}{l}\text { Web } \\
\text { slenderness } \\
h / t\end{array}$ & $\begin{array}{l}\text { Hole diameter } \\
\text { ratio } \\
a / h\end{array}$ & $\begin{array}{l}\text { Exp. load per } \\
\text { web } \\
P_{\text {EXP }} \\
(\mathrm{kN})\end{array}$ & $\begin{array}{l}\text { Web crippling strength per } \\
\text { web predicted from FEA } \\
P_{\text {FEA }} \\
(\mathrm{kN})\end{array}$ & $\begin{array}{l}\text { Comparison } \\
P_{\text {EXP }} / P_{\text {FEA }}\end{array}$ \\
\hline ETF142 × $60 \times 13-\mathrm{t} 1.3 \mathrm{~N} 90 \mathrm{MA0FR}$ & 113.8 & 0.0 & 2.21 & 2.18 & 1.01 \\
\hline ETF142 $\times 60 \times 13-\mathrm{t} 1.3 \mathrm{~N} 90 \mathrm{MA0} .2 \mathrm{FR}$ & 113.8 & 0.2 & 1.98 & 1.94 & 1.02 \\
\hline ETF142 $\times 60 \times 13-\mathrm{t} 1.3 \mathrm{~N} 90 \mathrm{MA0.4FR}$ & 112.2 & 0.4 & 1.62 & 1.69 & 0.96 \\
\hline ETF142 $\times 60 \times 13-\mathrm{t} 1.3$ N90MA0.6FR & 112.2 & 0.6 & 1.32 & 1.41 & 0.94 \\
\hline ETF142 $\times 60 \times \times 13-t 1.3 N 120 M A 0 F R$ & 112.5 & 0.0 & 2.35 & 2.63 & 0.89 \\
\hline ETF142 × $60 \times 13-\mathrm{t} 1.3 \mathrm{~N} 120 \mathrm{MA0} .2 \mathrm{FR}$ & 112.5 & 0.2 & 1.95 & 2.30 & 0.85 \\
\hline ETF142 × $60 \times 13-t 1.3 N 120 M A 0.4 F R$ & 112.4 & 0.4 & 1.78 & 1.95 & 0.91 \\
\hline ETF142 × $60 \times 13-\mathrm{t} 1.3 \mathrm{~N} 120 \mathrm{MA0} 0.6 \mathrm{FR}$ & 112.4 & 0.6 & 1.49 & 1.62 & 0.92 \\
\hline ETF172 × $65 \times 13-\mathrm{t} 1.3 \mathrm{~N} 120 \mathrm{MAOFR}$ & 134.5 & 0.0 & 2.37 & 2.28 & 1.04 \\
\hline ETF172 × $65 \times 13-\mathrm{t} 1.3 \mathrm{~N} 120 \mathrm{MA0} .4 \mathrm{FR}$ & 134.1 & 0.4 & 1.70 & 1.81 & 0.94 \\
\hline ETF172 × $65 \times 13-\mathrm{t} 1.3 \mathrm{~N} 120 \mathrm{MA0.6FR}$ & 133.3 & 0.6 & 1.36 & 1.48 & 0.92 \\
\hline ETF202 $\times 65 \times 13-\mathrm{t} 1.4 \mathrm{~N} 120 \mathrm{MAOFR}$ & 137.4 & 0.0 & 2.70 & 2.87 & 0.94 \\
\hline ETF202 × $65 \times 13-\mathrm{t} 1.4 \mathrm{~N} 120 \mathrm{MA0.2FR}$ & 137.8 & 0.2 & 2.41 & 2.46 & 0.98 \\
\hline ETF202 × $65 \times 13-\mathrm{t} 1.4 \mathrm{~N} 120 \mathrm{MA0.4FR}$ & 137.6 & 0.4 & 1.88 & 2.01 & 0.94 \\
\hline ETF202 $\times 65 \times 13-\mathrm{t} 1.4 \mathrm{~N} 150 \mathrm{MAOFR}$ & 137.4 & 0.0 & 2.84 & 3.29 & 0.86 \\
\hline ETF202 × $65 \times 13-\mathrm{t} 1.4 \mathrm{~N} 150 \mathrm{MA0.4FR}$ & 137.8 & 0.4 & 2.19 & 2.35 & 0.93 \\
\hline ETF202 × $65 \times 13-\mathrm{t} 1.4 \mathrm{~N} 150 \mathrm{MA0.6FR}$ & 137.6 & 0.6 & 1.77 & 1.90 & 0.93 \\
\hline ETF262 $\times 65 \times 13-\mathrm{t} 1.6 \mathrm{~N} 120 \mathrm{MAOFR}$ & 166.9 & 0.0 & 2.55 & 2.88 & 0.89 \\
\hline ETF262 × $65 \times 13-\mathrm{t} 1.6 \mathrm{~N} 120 \mathrm{MA0} .2 \mathrm{FR}$ & 166.9 & 0.2 & 2.29 & 2.29 & 1.00 \\
\hline ETF262 × $65 \times 13-\mathrm{t} 1.6 \mathrm{~N} 120 \mathrm{MA0} .4 \mathrm{FR}$ & 167.5 & 0.4 & 1.77 & 1.85 & 0.96 \\
\hline ETF262 × $65 \times 13-\mathrm{t} 1.6 \mathrm{~N} 150 \mathrm{MAOFR}$ & 166.9 & 0.0 & 2.82 & 3.19 & 0.88 \\
\hline ETF262 $\times 65 \times 13-\mathrm{t} 1.6 \mathrm{~N} 150 \mathrm{MA0.4FR}$ & 167.5 & 0.4 & 2.04 & 2.09 & 0.98 \\
\hline Mean & & & & & 0.94 \\
\hline $\mathrm{COV}$ & & & & & 0.05 \\
\hline
\end{tabular}

that good agreement is achieved between the experimental and finite element results for both the web crippling strength and the failure mode.

\section{Conclusions}

An experimental and numerical investigation of lipped channel sections with and without circular web holes subjected to web crippling have been presented. A series of tests was conducted on lipped channel sections with web holes subject to the interior- two-flange (ITF) and end-two-flange (ETF) loading conditions in which the web holes were located at the mid-depth of the webs and centred beneath the bearing plates. The web slenderness value of the specimens ranged from 31.8 to 176.9. The diameter of the web holes was varied in order to investigate the influence of the web holes on the web crippling strength. The cases of the flanges of the channel sections being fastened and unfastened to the bearing plates was also considered.

A finite element model that incorporated the geometric and material nonlinearities has been developed and verified against the experimental results. The finite element model was shown to 
Table 9

Comparison of web crippling strength predicted from finite element analysis with experiment results for fastened flanges under ETF loading condition.

\begin{tabular}{|c|c|c|c|c|c|}
\hline Specimen & $\begin{array}{l}\text { Web } \\
\text { slenderness } \\
h / t\end{array}$ & $\begin{array}{l}\text { Hole diameter } \\
\text { ratio } \\
a / h\end{array}$ & $\begin{array}{l}\text { Exp. load } \\
\text { per web } \\
P_{\text {EXP }} \\
(\mathrm{kN})\end{array}$ & $\begin{array}{l}\text { Web crippling strength per } \\
\text { web predicted from FEA } \\
P_{\text {FEA }} \\
(\mathrm{kN})\end{array}$ & $\begin{array}{l}\text { Comparison } \\
P_{\text {EXP }} / P_{\text {FEA }}\end{array}$ \\
\hline ETF142 × $60 \times 13$-t1.3N90MA0FX & 113.8 & 0.0 & 3.75 & 3.73 & 1.01 \\
\hline ETF142 $\times 60 \times 13-\mathrm{t} 1.3 \mathrm{~N} 90 \mathrm{MA0.2FX}$ & 113.8 & 0.2 & 3.16 & 3.48 & 0.91 \\
\hline ETF142 $\times 60 \times 13-\mathrm{t} 1.3 \mathrm{~N} 90 \mathrm{MA0.4FX}$ & 112.2 & 0.4 & 2.79 & 3.13 & 0.89 \\
\hline ETF142 $\times 60 \times 13-\mathrm{t} 1.3 \mathrm{~N} 90 \mathrm{MA0} .6 \mathrm{FX}$ & 112.2 & 0.6 & 2.55 & 2.73 & 0.93 \\
\hline ETF142 × $60 \times 13-t 1.3 N 120$ MAOFX & 112.5 & 0.0 & 4.06 & 4.51 & 0.90 \\
\hline ETF142 × $60 \times 13-\mathrm{t} 1.3 \mathrm{~N} 120 \mathrm{MA0} 0.2 \mathrm{FX}$ & 112.5 & 0.2 & 3.58 & 4.19 & 0.85 \\
\hline ETF142 × $60 \times 13-\mathrm{t} 1.3 \mathrm{~N} 120 \mathrm{MA0} 0.4 \mathrm{FX}$ & 112.4 & 0.4 & 3.44 & 3.78 & 0.91 \\
\hline ETF142 × $60 \times 13-\mathrm{t} 1.3 \mathrm{~N} 120 \mathrm{MA0} .6 \mathrm{FX}$ & 112.4 & 0.6 & 2.94 & 3.36 & 0.88 \\
\hline ETF172 × $65 \times 13-t 1.3 N 120 M A 0 F X$ & 134.5 & 0.0 & 4.16 & 4.51 & 0.92 \\
\hline ETF172 × $65 \times 13-\mathrm{t} 1.3 \mathrm{~N} 120 \mathrm{MA0} .4 \mathrm{FX}$ & 134.1 & 0.4 & 3.48 & 3.69 & 0.94 \\
\hline ETF172 × $65 \times 13-\mathrm{t} 1.3 \mathrm{~N} 120 \mathrm{MA0.6FX}$ & 133.3 & 0.6 & 3.00 & 3.24 & 0.93 \\
\hline ETF202 $\times 65 \times 13-t 1.4$ N120MAOFX & 137.4 & 0.0 & 5.24 & 5.29 & 0.99 \\
\hline ETF202 × $65 \times 13-\mathrm{t} 1.4 \mathrm{~N} 120 \mathrm{MA0} 0.2 \mathrm{FX}$ & 137.8 & 0.2 & 4.88 & 4.78 & 1.02 \\
\hline ETF202 × $65 \times 13-\mathrm{t} 1.4 \mathrm{~N} 120 \mathrm{MA0.4FX}$ & 137.6 & 0.4 & 4.27 & 4.22 & 1.01 \\
\hline ETF202 $\times 65 \times 13-\mathrm{t} 1.4 \mathrm{~N} 150 \mathrm{MAOFX}$ & 137.4 & 0.0 & 5.82 & 6.10 & 0.95 \\
\hline ETF202 × $65 \times 13-\mathrm{t} 1.4 \mathrm{~N} 150 \mathrm{MA0} 0.4 \mathrm{FX}$ & 137.8 & 0.4 & 4.73 & 4.97 & 0.95 \\
\hline ETF202 × $65 \times 13-t 1.4$ N150MA0.6FX & 137.6 & 0.6 & 4.24 & 4.35 & 0.97 \\
\hline ETF262 $\times 65 \times 13-t 1.6 N 120$ MA0FX & 166.9 & 0.0 & 5.06 & 5.05 & 1.00 \\
\hline ETF262 × $65 \times 13-\mathrm{t} 1.6 \mathrm{~N} 120 \mathrm{MA0} 0.2 \mathrm{FX}$ & 166.9 & 0.2 & 4.60 & 4.51 & 1.02 \\
\hline ETF262 × $65 \times 13-\mathrm{t} 1.6 \mathrm{~N} 120 \mathrm{MA0.4FX}$ & 167.5 & 0.4 & 3.89 & 3.88 & 1.00 \\
\hline ETF262 × $65 \times 13-t 1.6 N 150 M A 0 F X$ & 166.9 & 0.0 & 5.37 & 5.72 & 0.94 \\
\hline ETF262 × $65 \times 13-\mathrm{t} 1.6 \mathrm{~N} 150 \mathrm{MA0.4FX}$ & 167.5 & 0.4 & 4.25 & 4.51 & 0.94 \\
\hline Mean & & & & & 0.95 \\
\hline $\mathrm{COV}$ & & & & & 0.05 \\
\hline
\end{tabular}

be able to closely predict the web crippling behaviour of the channel sections, both with and without circular web hole. The new web crippling test data presented in this paper can be used to develop design rules for cold-formed steel sections.

\section{Acknowledgements}

The Authors gratefully acknowledge the help given by Metsec Plc, UK, in supplying the materials. The authors also wish to thank $\mathrm{Mr}$ Chris Cameron and Mr Andrew Crockett for their assistant in preparing the specimens and carrying out the experimental testing.

\section{References}

[1] Rhodes J, Nash D. An investigation of web crushing behaviour in thin-walled beams. Thin-Walled Structures 1998;32:207-30.
[2] Uzzaman A, Lim JBP, Nash D, Rhodes J, Young B. Web crippling behaviour of cold-formed steel channel sections with offset web holes subjected to interior-two-flange loading. Thin-Walled Structures 2012;50:76-86.

[3] Yu WW, Davis CS. Cold-formed steel members with perforated elements. Journal of the Structural Division 1973;99:2061-77.

[4] Sivakumaran KS, Zielonka KM. Web crippling strength of thin-walled steel members with web openings. Thin-Walled Structures 1989;8:295-319.

[5] LaBoube RA, Yu WW, Deshmukh SU, Uphoff CA. Crippling capacity of web elements with openings. Journal of Structural Engineering 1999;125:137-41.

[6] Chung KF. Structural perfomance of cold formed sections with single and multiple web openimgs. (Part-1 Experimental investigation). The Structural Engineer 1995;73.

[7] Zhou F, Young B. Web crippling of aluminium tubes with perforated webs. Engineering Structures 2010;32:1397-410.

[8] ANSYS, User's manual, Revision 11.0, in, Swanson Analysis System, 2011.

[9] NAS, North American Specification for the Design of Cold-Formed Steel Structural Members, American Iron and Steel Institute, AISI S100-2007, AISI Standard, 2007.

[10] EN, 10002-1: 2001. Tensile testing of metallic materials. Method of test at ambient temperature, British Standards Institution, 2001. 